MICHAE BASA

\title{
INSTYTUCJA ŁAWNIKÓW SĄDU NAJWYŻSZEGO
}

\section{LAWNIK W POLSKIM PORZĄDKU PRAWNYM}

Nowa ustawa o Sądzie Najwyższym weszła w życie 3 kwietnia 2018 r. ${ }^{1}$ Przyniosła ze soba wiele rewolucyjnych zmian w organizacji wymiaru sprawiedliwości (m.in. utworzenie dwóch nowych izb SN, zmianę kształtu postępowań dyscyplinarnych wobec sędziów i prokuratorów, implementację skargi nadzwyczajnej) oraz wprowadziła w życie instytucję ławników SN. Po raz pierwszy w historii ustroju państwa polskiego ławnicy zasiedli w składach orzekających Najwyższej Instancji Sądowej.

Obecność ławnika w organach wymiaru sprawiedliwości nie jest w prawie polskim nowością. W tradycji prawnej wykształciły się dwie podstawowe formy bezpośredniego udziału społeczeństwa w sprawowaniu wymiaru sprawiedliwości: sądy ławnicze i sądy przysięgłych ${ }^{3}$. Sądy zawodowo-ławnicze stanowia dominujaccy model w Europie ${ }^{4}$. Drugi z modeli charakteryzuje się istnieniem odseparowanych od siebie: sądu przysięgłych (złożonego z podmiotów niemających przygotowania fachowego, a podejmujących decyzję o uznaniu oskarżonego za winnego lub o uniewinnieniu) i sędziego zawodowego (decydującego o subsumpcji i ewentualnym rodzaju i wymiarze kary ${ }^{5}$ ). Rzeczony model nie przyją się w Polsce mimo dwukrotnej próby jego implementacji ${ }^{6}$. W krajowym porządku prawnym znalazł jednak podatny grunt model ławniczy, który zakłada orzekanie w sądach I instancji w sprawach, które wymagaja pewnego zaangażowania społecznego przez składy o przewadze ławników pod przewodnictwem sędziego zawodowego. Omawiane rozwiązanie towarzyszy polskiemu systemowi prawnemu od wejścia w życie Konstytucji z 1921 r. i z nielicznymi wyjątkami obowiązuje do dzisiaj, choć widoczna jest stała tendencja do zmniejszania puli spraw, w których orzekają ławnicy ${ }^{7}$ W tym zakresie szcze-

\footnotetext{
${ }^{1}$ Ustawa z 8 grudnia 2017 r. o Sądzie Najwyższym, t.jedn.: Dz. U. 2019, poz. 825 (dalej jako: ustawa o $\mathrm{SN}$ ).

${ }^{2}$ Wenclik (2011): 65; również Śliwiński (b.r.): 862.

${ }^{3}$ Waszczyński (1969): 79.

${ }^{4}$ Kutnjak Ivkovic (2003): 94.

${ }^{5}$ Kutnjak Ivkovic (2003): 65-66.

${ }^{6} \mathrm{~W}$ okresie przed II wojną światową sądy przysięgłych w szczątkowym zakresie działały na obszarze właściwości apelacji krakowskiej i lwowskiej - zniesiono je jednak ostatecznie w 1938 r. zob. Rybicki (1968): 83; drugą próbę implementacji tego rodzaju sądów podjęto na krótko w $1944 \mathrm{r}$. i miała charakter manifestu politycznego - zob. Rybicki (1968): 124-126.

${ }^{7}$ Ograniczenie przez ustawę z 19 kwietnia 1969 r. - Kodeks postępowania karnego (Dz. U. 1969, Nr 13, poz. 96) oraz ustawę z 17 listopada 1964 r. - Kodeks postępowania cywilnego
} 
gólne znaczenie miała ustawa z 15 marca 2007 r. o zmianie ustawy - Kodeks postępowania cywilnego, ustawy - Kodeks postępowania karnego oraz o zmianie niektórych innych ustaw, która wyłączyła zasadę, jaką było rozpoznawanie spraw przez sądy karne w I instancji w składach ławniczych, zawężając ją obecnie wyłącznie do spraw o zbrodnie.

Udział ławników w sprawowaniu wymiaru sprawiedliwości wynika wprost z przepisów Konstytucji RP. Zgodnie z art. 182 ustawy zasadniczej udział obywateli w sprawowaniu wymiaru sprawiedliwości określa ustawa. Brzmienie powołanego przepisu implikuje trzy konsekwencje: udział ten jest obowiązkowy, nie można go całkowicie wykluczyć, a jego szczegółową formę określają przepisy ustawowe ${ }^{8}$. Przepis art. 182 Konstytucji RP jest zatem normą kompetencyjno-odsyłającą i sam w sobie nie stwarza ram udziału czynnika społecznego w sprawowaniu wymiaru sprawiedliwości ${ }^{9}$. Dlatego też trudno mówić o konstytucyjnym modelu udziału czynnika społecznego, a tym bardziej sędziów społecznych w sprawowaniu wymiaru sprawiedliwości. Na gruncie obecnego brzmienia art. 182 Konstytucji RP dopuszczalne jest zarówno wprowadzenie sądów przysięgłych, jak i sądów ławniczych. Nic jednak zdaje się nie prognozować modelowych zmian. Nie należy przy tym tracić z pola widzenia, że niezależnie od formy realizacji zasady, o której mowa w art. 182 Konstytucji RP, jej zmarginalizowanie może prowadzić do zachwiania fundamentami demo$\mathrm{kracji}^{10}$. Przed 3 kwietnia 2018 r. obowiązywał model udziału czynnika społecznego w sprawowaniu wymiaru sprawiedliwości, który zakładał partycypację ławników w składach sądów w sprawach, w których niezbędna była pewna wrażliwość społeczna i silniejsze niż zazwyczaj poddanie procesu społecznej kontroli. Z woli ustawodawcy była to grupa spraw: pracowniczych (art. $47 \S 2$ pkt 1 k.p.c.), niektórych rodzinnych (art. $47 \S 2$ pkt 2 i 509 k.p.c.), o zbrodnie rozpoznawanych przez sądy okręgowe (art. $28 \S 2$ k.p.k.) bądź o czyny zagrożone karą dożywotniego pozbawienia wolności (art. $28 \S 4$ k.p.k.). Kodeks postępowania karnego dopuszcza fakultatywne konstruowanie składów ławniczych przed sądami I instancji, jako alternatywy dla rozpoznania sprawy w składzie trzyosobowym zawodowym (art. 28 § 3 k.p.k.). Obserwacja praktyki dowodzi jednak, że takie rozwiązania należą do rzadkości. Nie brakuje głosów, że regulacja przepisu art. $28 \S 3$ k.p.k. jest w gruncie rzeczy fasadowa ${ }^{11}$.

Pozycję ustrojowa ławnika wyznaczały dotychczas przepisy art. 4 i rozdziału 7 p.u.s.p. ${ }^{12}$ Pierwszy z nich stanowi, że przy rozstrzyganiu spraw ławnicy mają równe prawa z sędziami i asesorami sądowymi. Cytowany przepis jest

(t.jedn.: Dz. U. 2019, poz. 1460) udziału ławników w rozpoznawaniu spraw cywilnych i karnych, czy przez ustawę z 15 marca 2007 r. o zmianie ustawy - Kodeks postępowania cywilnego, ustawy - Kodeks postępowania karnego oraz o zmianie niektórych innych ustaw (Dz. U. 2007, Nr 112 poz. 766) zmieniającej brzmienie art. $47 \S 2$ k.p.c. i art. 28 § 1-4 k.p.k.

${ }^{8}$ Wiliński, Karlik (2016).

${ }^{9}$ Wiliński, Karlik (2016) oraz wyrok TK z 29 listopada 2005 r., P 16/04, Dz. U. 2005, Nr 241, poz. 2037: 15899 .

${ }^{10}$ Waltoś (2011): 526.

11 Jakubik (2014): 48.

${ }^{12}$ Ustawa z 27 lipca 2001 r. - Prawo o ustroju sądów powszechnych, t.jedn.: Dz. U. 2019, poz. 52 (dalej jako: p.u.s.p.). 
jednocześnie deklaracją ustawodawcy, która sędziom społecznym nadaje takie same prawa ${ }^{13}$, jak sędziom zawodowym.

Zasadniczą funkcją ławnika jest społeczne uwrażliwienie procesu, poddanie go kontroli obywatelskiej ${ }^{14}$ i zwiększenie zaufania obywateli do organów wymiaru sprawiedliwości ${ }^{15}$. Udział ławnika w składzie orzekającym jest także gwarancją rozstrzygania spraw w sposób kolegialny ${ }^{16}$. Konsekwencją kolegialności jest prowadzenie narad, dyskusji, ścierania poglądów i różnych zapatrywań na te same kwestie ${ }^{17}$. Choć ten sam efekt można osiagnąć, konstruując składy wyłącznie zawodowe, to z punktu widzenia wymiaru sprawiedliwości udział ławnika jest korzystny, ponieważ sprawia, że pogląd składu sędziowskiego staje się bardziej wszechstronny ${ }^{18}$. Kolegialność orzekania, rozkładająca odpowiedzialność za orzeczenie na wszystkich członków składu staje się także rękojmią niezawisłości ${ }^{19} \mathrm{i}$ gwarancją takiego wizerunku sądu ${ }^{20}$. Ławnik jest łącznikiem sądu i społeczeństwa, co działa w dwie strony, do składu wnosi bowiem pogląd społeczny, a do społeczeństwa - zrozumienie ${ }^{21} \mathrm{i}$ aprobatę wydawanych orzeczeńn ${ }^{22}$. W tym sensie ławnik staje się gwarantem legitymacji demokratycznej wyroku sądowego ${ }^{23}$. W piśmiennictwie zagranicznym zauważa się z kolei, że główną funkcją sędziów społecznych jest ochrona sędziów zawodowych przed orzekaniem w sposób rutynowy ${ }^{24}$.

\section{ZAGADNIENIE UDZIALU SĘDZIÓW SPOŁECZNYCH W POSTĘPOWANIU ODWOŁAWCZYM}

Większość przedstawicieli doktryny stoi na stanowisku, że ławnicy biora udział wyłącznie w postępowaniu przed sądem I instancji ${ }^{25}$. Wskazuje się jednak, że na gruncie analizy językowej przepisu art. 182 Konstytucji RP, ławnicy mogą brać udział w postępowaniu przed sądem każdej instancji, nie wyłączając SN. Na taką ewentualność musi zezwolić prawodawca w drodze ustawy. Dotychczas taka możliwość wydawała się sprzeczna z pozycja ustrojową i zadaniami stojacymi przed tym organem władzy sąowniczejej. $\mathrm{Z}$ podobnych przyczyn trudno wyobrazić sobie udział ławników w postępo-

13 Rybicki (1964): 6.

14 Śliwiński (b.r.): 864.

15 Małolepszy, Głuchowski (2018): 99.

16 Prusak (1975): 28.

17 Jakubik (2014): 45.

18 Prusak (1975): 28-29; odmiennie Jakubik (2014): 44, który twierdzi, że kolegialność orzekania nierozerwalnie wiąże się z udziałem czynnika społecznego.

19 Jakubik (2014): 45, podobnie Klubińska (2018): 16.

${ }^{20}$ Klubińska (2018): 21 i cytowana tam literatura.

21 Waszczyński (1969): 83.

22 Waszczyński (1969): 29.

${ }^{23}$ Kutnjak Ivkovic (2003): 98.

${ }^{24}$ Kutnjak Ivkovic (2003): 96.

25 Masternak-Kubiak (2014): 461.

26 Wiliński, Karlik (2016). 
waniach przed sądami odwoławczymi. W postępowaniu odwoławczym pożądana jest głęboka znajomość przepisów prawa, poglądów orzecznictwa i doktryny, której ławnicy nie posiadaja ${ }^{27}$. Podstawową funkcja postępowania odwoławczego jest funkcja kontrolna, której sprawowanie bez fachowej wiedzy prawniczej jest iluzoryczne ${ }^{28}$. Z przekonania o niecelowości udziału ławników w postępowaniach odwoławczych wychodzi Andrzej Murzynowski, który dostrzega, że sądy II instancji koncentrują się w głównej mierze na rozstrzyganiu zawiłych postępów prawnych, stąd nie może być w nich miejsca dla ławników ${ }^{29}$. Ugruntowało się także przekonanie, że zawiłość sprawy, zwłaszcza jeśli występuje na gruncie zastosowania prawa, $\mathrm{z}$ reguły powinna prowadzić do wyznaczania trzyosobowego składu zawodowego ${ }^{30}$. Inny stan rzeczy prezentuje prawodawstwo niemieckie, które przewiduje udział ławników w postępowaniu przed sądem odwoławczym (dwóch ławników i jeden sędzia zawodowy lub dwóch ławników i dwóch sędziów zawodowych) ${ }^{31}$. Mieszany skład sądu II instancji rozpoznaje środki odwoławcze wniesione od orzeczeń sądu orzekającego w składzie jednego sędziego zawodowego lub sędziego i dwóch ławników ${ }^{32}$.

W odniesieniu do instytucji ławników SN należy rozważyć, dlaczego ustawodawca, który nie dopuszcza ławników do orzekania w postępowaniu przed sądem II instancji i preferuje w nich składy trzyosobowe lub pięcioosobowe zawodowe (art. $29 \S 1$ i 2 k.p.k.) lub na zasadzie wyjatku jednoosobowe zawodowe (art. 449 § 2 k.p.k.), pozwolił, by w składach sądu mogącego sprawować nadzór nad SN (przez instytucję skargi nadzwyczajnej) zasiedli sędziowie społeczni. Przyjęte rozwiązanie jest niekonsekwentne i dowodzi asymetrii preferencji aksjologicznych prawodawcy, który powierza kontrolę orzeczeń wydanych w składach ławniczych sędziom zawodowym, wyłącznie po to, by orzeczenie składu zawodowego poddać kontroli składu ławniczego. Jednocześnie w osobie ławnika (mimo że dysponuje prawami równymi z sędzią i asesorem) widzi się raczej sędziego faktu niż sędziego prawa ${ }^{33}$. Powyższe zapatrywanie skonfrontowane z zakresem kognicji Izby Kontroli Nadzwyczajnej i Izby Dyscyplinarnej SN nakazuje rozważyć, czy osoby nieposiadające rozległej, fachowej wiedzy prawniczej wniosa istotny, merytoryczny wkład do orzecznictwa tych Izb. Daleko posunięta specyfika spraw rozpoznawanych w Izbie Dyscyplinarnej oraz Izbie Kontroli Nadzwyczajnej i Spraw Publicznych stawia pod znakiem zapytania możliwość realizacji postulatu dostosowania stopnia skomplikowania prawa do poziomu percepcji nieprofesjonalistów, którzy będą się nim zajmować ${ }^{34}$.

\footnotetext{
27 Prusak (1975): 31.

${ }^{28}$ Klubińska (2018): 24.

29 Murzynowski (1994): 241.

${ }^{30}$ Kosonoga (2016): 89-90.

31 Małolepszy, Głuchowski (2018): 88.

32 Małolepszy, Głuchowski (2018): 88.

${ }^{33}$ Prusak (1975): 36.

${ }^{34}$ Pożaroszczyk (2013): 180.
} 


\section{RATIO LEGIS INSTYTUCJI ŁAWNIKÓW SN}

Prawodawca motywuje udział sędziów społecznych w postępowaniach toczących się w Izbie Dyscyplinarnej i Izbie Kontroli Nadzwyczajnej koniecznością podkreślenia jawności i społecznej kontroli spraw toczących się przez SN. Wprowadzenie nowej instytucji ustawodawca uzasadnia następująco: „Udział ławników w składach orzekających w sprawach skarg nadzwyczajnych wprowadzi bardzo ważny element kontroli społecznej w sprawach, w których mogły zostać naruszone podstawowe elementy zasady sprawiedliwości społecznej. [...] Wprowadzenie mieszanych składów sądu dyscyplinarnego (sędziowsko-ławniczych) ma na celu zwiększenie udziału społeczeństwa w rozpatrywaniu spraw dyscyplinarnych sędziów Sądu Najwyższego. Udział ten, ze względu na pozycję, jaką zajmuje Sąd Najwyższy w hierarchii organów wymiaru sprawiedliwości oraz powierzone mu istotne zadania w zakresie stosowania prawa, staje się uzasadniony. Tego rodzaju regulacja urzeczywistnia kontrolę społeczna, zwiększa transparentność postępowań dyscyplinarnych i wpływa na zwiększenie zaufania obywateli do sędziów Sądu Najwyższego przy jednoczesnym zachowaniu profesjonalnego charakteru składu sędziowskiego" ${ }^{35}$.

Ławnicy SN nie będą uczestniczyć w rozpoznawaniu wszystkich spraw pozostających w kognicji Najwyższej Instancji Sądowej. Z woli ustawodawcy, zasiąda oni w składach rozpoznajacych sprawy dyscyplinarne i wywołane wniesieniem skargi nadzwyczajnej (art. 59 § 1 ustawy o SN). Zakres tych spraw określają stosowne przepisy dotyczące właściwości Izby Dyscyplinarnej (art. 27 § 1-4 ustawy o SN). Mowa zatem o sprawach dyscyplinarnych sędziów SN, sprawach dyscyplinarnych adwokatów, radców prawnych, notariuszy, sędziów i prokuratorów w zakresie, w jakim toczą się przed SN i poważnych przewinień dyscyplinarnych sędziów sądów powszechnych i prokuratorów, rozpoznawanych w I instancji przez SN. Ławnicy SN będą także brali udział w rozpoznawaniu skarg nadzwyczajnych, a więc metaśrodków zaskarżenia, które mogą być wywiedzione od prawomocnego orzeczenia sądu wojskowego i powszechnego kończącego postępowanie w sprawie, jeżeli jest to konieczne, aby zapewnić zgodność z zasada demokratycznego państwa prawnego urzeczywistniającego zasady sprawiedliwości społecznej (art. 89 § 1 ustawy o SN).

Ławnicy SN zgodnie z utrwaloną tradycją prawną będą orzekać w składach mieszanych, zawsze obok sędziów zawodowych. Zasada wyrażona w art. 59 § 2 ustawy o SN przyjmuje standardowy skład 2 sędziów zawodowych i 1 ławnika SN. Powyższy skład powtórzony jest $\mathrm{w}$ innych przepisach nowej ustawy (art. $94 \S 1$, art. $73 \S 1$ pkt 1 ustawy o SN). Ustawodawca przewidział także konstruowanie składu 7-osobowego (5 sędziów SN i 2 ławników SN) w przypadku, w którym skarga nadzwyczajna wywodzona jest od orzeczenia SN.

${ }^{35}$ Druk sejmowy nr 2003, Sejm VIII kadencji, prezydencki projekt ustawy o Sądzie Najwyższym: 8 i 11, dostępny na: <http://orka.sejm.gov.pl/Druki8ka.nsf/0/5AB89A44A6408C3CC12581D800339FED/\%24File/2003.pdf> [dostęp: 18.02.2020]. 
Przepis art. $94 \S 2$ ustawy o SN został znowelizowany. Obecnie ${ }^{36}$ ustawa przewiduje taki skład przy rozpoznawaniu skargi nadzwyczajnej wywodzonej od orzeczenia „zapadłego w wyniku postępowania, w którego toku orzeczenie wydał Sąd Najwyższy". Na gruncie powyższego zagadnienia wynikły istotne problemy interpretacyjne. Postanowieniem z 4 lipca 2019 r. ${ }^{37} \mathrm{SN}$ - Izba Kontroli Nadzwyczajnej i Spraw Publicznych przedstawiła składowi 7 sędziów SN do rozstrzygnięcia następujące zagadnienie prawne: „Czy oddalenie przez Sąd Najwyższy kasacji wniesionej od orzeczenia sądu powszechnego, od którego została następnie wniesiona rozpoznawana skarga nadzwyczajna, oznacza, że Sąd Najwyższy oddalając kasację wydał orzeczenie w "toku postępowania" w rozumieniu art. $94 \S 2$ u.SN, a w konsekwencji, że Sąd Najwyższy rozpoznaje skargę nadzwyczajną wniesioną w takiej sytuacji procesowej w składzie 5 sędziów Sądu Najwyższego orzekających w Izbie Kontroli Nadzwyczajnej i Spraw Publicznych oraz 2 ławników Sądu Najwyższego, czy też, zgodnie z treścią art. $94 \S 1$ tej ustawy - w składzie 2 sędziów Sądu Najwyższego orzekających w Izbie Kontroli Nadzwyczajnej i Spraw Publicznych oraz 1 ławnika Sądu Najwyższego?”. Waga zagadnienia jest tym większa, że w świetle art. 95 pkt 2 ustawy o SN w zw. z art. $439 \S 1$ pkt 2 k.p.k. niewłaściwy skład sądu rozpoznającego skargę nadzwyczajną obciąża postępowanie wywołane wniesieniem skargi kwalifikowaną wadą $\mathrm{w}$ postaci bezwzględnej przyczyny odwoławczej.

Nie powtarzając w tym miejscu argumentów podniesionych przez skład SN, który wydał przytoczone postanowienie, opowiadam się przeciwko rozpoznawaniu skarg nadzwyczajnych przez poszerzony skład w stanie faktycznym przedstawionym w sprawie I NSNk 1/18. Kasacja jest nadzwyczajnym środkiem zaskarżenia wywodzonym od prawomocnych wyroków. Jeśli kasacja zostanie oddalona, jej wniesienie nie wywiera wpływu na treść orzeczenia wydanego i skontrolowanego w postępowaniu karnym przed sądem powszechnym. Jednocześnie funkcją skargi nadzwyczajnej nie jest kontrola prawidłowości rozstrzygnięcia sądu kasacyjnego, skoro oba postępowania różnią się od siebie w sposób zasadniczy. O ile bowiem kasacja jest typowym nadzwyczajnym środkiem zaskarżenia, stanowiącym logiczne uzupełnienie modelu apelacyjnego ${ }^{38}$, o tyle skardze nadzwyczajnej bliżej do modelu rewizyjnego ${ }^{39}$. Przy tym w skardze nadzwyczajnej możliwe jest podnoszenie uchybień w zakresie rekonstrukcji stanu faktycznego, które nie mogą być przedmiotem rozpoznania w postępowaniu kasacyjnym ${ }^{40}$ (art. $89 \S 1$ pkt 3 ustawy o SN; tego rodzaju zarzuty podniesiono w sprawie I NSNk 1/18), a warunkiem wniesienia skargi nadzwyczajnej jest brak możliwość uchylenia lub zmiany orzeczenia wskutek

36 Przepis zmieniono na mocy art. 2 ustawy z 10 maja 2018 r. o zmianie ustawy - Prawo o ustroju sądów powszechnych, ustawy o Sądzie Najwyższym oraz niektórych innych ustaw, Dz. U. 2018, poz. 1045.

37 Postanowienie SN - Izby Kontroli Nadzwyczajnej i Spraw Publicznych z 4 lipca 2019 r., I NSNk 1/18, <www.sn.pl>.

38 Kotowski (2018): 57; Rogacka-Rzewnicka (2001): 206.

39 Kotowski (2018): 60.

40 Grzegorczyk (2015): 24. 
innego, nadzwyczajnego środka zaskarżenia (art. 89 § 1 in fine ustawy o SN). Skarga nadzwyczajna jedynie uzupełnia model nadzwyczajnych środków zaskarżenia. Jej zadaniem nie jest kontrola prawidłowości „negatywnego” orzeczenia sądu kasacyjnego, która przemawiałaby za konstruowaniem składu rozszerzonego - jak choćby w przepisie art. 534 § 2 k.p.k. W sytuacji pośredniej kontroli orzeczenia sądu kasacyjnego (zapadłego w warunkach związania zapatrywaniami sądu kasacyjnego (art. 518 w zw. z art. 442 § 3 k.p.k.) konieczność rozpoznania skargi nadzwyczajnej w poszerzonym składzie jest uzasadniona (art. $94 \S 2$ ustawy o SN) ${ }^{41}$.

Skład 7-osobowy przewidziany jest także w postępowaniu odwoławczym w ramach postępowania dyscyplinarnego prowadzonego wobec sędziów SN. Znamienne, że w postępowaniach dyscyplinarnych prowadzonych przed SN Izbą Dyscyplinarną wobec sędziów sądów powszechnych i prokuratorów ustawodawca nie przewidział poszerzenia składu dla rozpoznania środka odwoławczego, wskazując, że zarówno w I instancji, jak i w II instancji sprawa rozpoznawana będzie w składzie 2 sędziów SN i 1 lawnika SN (art. 39a § 1 pkt 1 lit. b i pkt 2 p.u.s.p. oraz art. $145 \S 1$ pkt 1 lit. b i pkt 2 pr.prok. ${ }^{42}$ ). Powyższa analiza prowadzi do wniosku, że ławnicy w SN, niezależnie od składu, w którym będą zasiadać, zawsze będą w mniejszości. Ustawodawca przełamuje dotychczas stosowną w sądach I instancji zasadę przewagi sędziów społecznych w składach mieszanych (1 sędzia i 2 ławników, czy też 2 sędziów i 3 ławników). Rozwiązanie funkcjonujące przed sądami I instancji daje realną gwarancję wpływu sędziów społecznych na wydawane orzeczenia i przeciwdziała ich marginalizacji. Systemowa analiza k.p.k. prowadzi do wniosku, że ustawodawca zakłada poddanie takiego orzeczenia weryfikacji w postępowaniu odwoławczym, w składzie zawsze zawodowym. W postępowaniach, o których mowa w art. $59 \S 2$ ustawy o SN jest zgoła inaczej - ławnicy SN będą zatem jedynie doradczym głosem dla sędziów zawodowych.

\section{POWOŁANIE I ODWOŁANIE LAWNIKA SN A GWARANCJE JEGO NIEZAWISŁOŚCI}

Ławnik wchodzący w skład sądu rozpoznającego sprawę, musi legitymować się niezbędnymi gwarancjami bezstronności i niezawiłości. Powyższe wynika wprost $\mathrm{z}$ art. 45 ust. 1 Konstytucji RP i art. 6 ust. 1 Konwencji o ochronie praw człowieka i podstawowych wolności. Sąd (w tym skład zawodowo-ławniczy) musi spełniać takie warunki, jak: niezależność (zwłaszcza od władzy wykonawczej), bezstronność, odpowiednio długa kadencji jego członków, a tak-

${ }^{41}$ Tak również: Kluza (2019): 57; wskazuje on, że poszerzony skład rozpoznający skargę dotyczył będzie sytuacji, w której zaskarżone orzeczenie wydane zostało przez sąd powszechny, ale wcześniejsze orzeczenie zostało uchylone w wyniku kasacji.

${ }^{42}$ Ustawa z 28 stycznia 2016 r. - Prawo o prokuraturze, t.jedn.: Dz. U. 2019, poz. 740 (dalej jako: pr.prok.). 
że rękojmia odpowiednich gwarancji proceduralnych ${ }^{43}$. Branie przez ławnika udziału w orzekaniu nie pozwala na postrzeganie jego udziału w sprawowaniu wymiaru sprawiedliwości wyłącznie jako społecznej kontroli nad sędzią zawodowym, lecz wspólnego z sędziami zawodowymi rozpoznawania i rozstrzygania każdej sprawy, co przemawia za niezbędnymi ławnikowi przymiotami niezawisłości i bezstronności ${ }^{44}$. Sposób powołania ławnika SN ma zatem bezpośredni wpływ na rzetelność procesu. W wyroku z 29 listopada $2005 \mathrm{r}^{45} \mathrm{TK}$ zwraca uwagę na konieczność szczególnie uważnego i starannego konstruowania przepisów ustawowych dotyczących wyboru ławników: „Skoro bowiem ławnik uczestniczy w rozpatrywaniu i rozstrzyganiu pewnych kategorii spraw na zasadach identycznych jak sędzia, to procedura wyboru obywateli uczestniczących w sprawowaniu wymiaru sprawiedliwości nie jest obojętna z punktu widzenia zasady niezależności i odrębności sądów, a przez to również - z uwagi na związki treściowe pomiędzy art. 10 i 173 Konstytucji - zasady podziału władz”. Formalną deklarację niezawisłości ławników SN wyraża art. 67 ust. 1 ustawy o SN, zgodnie z którym w zakresie orzekania ławnicy SN są niezawiśli i podlegaja tylko Konstytucji oraz ustawom.

W doktrynie wskazuje się, że istnieją dwa możliwe systemy wyboru sędziów społecznych: wybory powszechne i tryb administracyjny, przy czym, pierwszy z nich nie jest prawidłowy, ponieważ pozbawia ławników właściwego mandatu i zaplecza społecznego niezbędnego do pełnienia powierzonych im funkcji ${ }^{46}$. Ustawodawca zdecydował się na zrównanie w prawach orzeczniczych ławników (w tym także ławników SN) i sędziów zawodowych. W tym kontekście duże wątpliwości budzi koncepcja wyboru (i odwoływania) sędziów społecznych przez Senat RP. Trudno dopatrywać się tych samych zagrożeń w procedurze wyboru ławników sądów powszechnych przez rady gmin, ponieważ są to organy znacznie bardziej zdecentralizowane i charakteryzujące się większym niż Senat pluralizmem. Nie należy tracić z pola widzenia, że Senat jest obecnie izbą dwupartyjną. Aktualizuje się zatem pytanie o to, czy ławnicy SN będą legitymować się dostatecznym mandatem demokratycznym. Nie bez przyczyny, w cytowanym już wyroku ${ }^{47}$ TK wskazywał, że wybór ławników jest tylko pewnym - aczkolwiek bardzo istotnym - elementem kształtowania personalnego składu sądu, rozumianego tu jako ciało kolegialne, sprawujące wymiar sprawiedliwości. Regulacja w tym zakresie musi być skonstruowana w taki sposób, aby nie dostarczała innym organom władzy instrumentów pozwalających na wpływanie przez te organy na niezależność sądów i niezawisłość sędziów w realizacji ich konstytucyjnej funkcji sprawowania wymiaru sprawiedliwości. Mając to na uwadze, należy rozważyć, czy przy utrzymaniu obecnego kształtu instytucji ławników SN nie należałoby upoważnić do ich wyboru (i odwoływania) organów uchwałodawczych jednostek samorządu te-

\footnotetext{
${ }^{43}$ Nowicki (2017) i cytowane tam orzecznictwo - w szczególności: wyrok Sutyagin v. Rosja z 3 maja 2011 r., Izba (Sekcja I), skarga nr 30024/02: § 187.

${ }^{44}$ Gudowski (2009): 649.

${ }^{45}$ Wyrok TK z 9 listopada 2005 r., P 16/04, Dz. U. 2005, Nr 241, poz. 2037: 15899.

${ }^{46}$ Prusak (1975): 41-42.

${ }^{47}$ Wyrok TK z 9 listopada 2005 r., P 16/04: 15899.
} 
rytorialnego (powiatów lub województw) lub wzorem rozwiązań niemieckich podzielić kompetencje wyboru ławników między organy władzy ustawodawczej i sądowniczej ${ }^{48}$. Gwarantowałoby to decentralizację wyborów, ściślejsze powiązanie ławników SN z lokalnymi społecznościami i większy pluralizm procedury wyborczej. Ponadto wywarłoby pozytywny wpływ na wzmocnienie mandatu demokratycznego ławników SN.

Przy ocenie sposobu powoływania i odwoływania ławników SN nie można pominąć art. 60 Konstytucji RP, zgodnie z którym obywatele polscy korzystajacy z pełni praw publicznych mają prawo dostępu do służby publicznej na jednakowych zasadach. Dlatego należy odrzuć pozornie kuszące możliwości wprowadzenia cenzusu majątkowego, czy cenzusu wykształcenia dla pełnienia funkcji publicznych o charakterze stricte społecznym. Podnosi się, że tak jak sędzia jest homo iuridicus, tak ławnik powinien być homo societas i charakteryzować się takim przymiotem moralnym jak poczucie sprawiedliwości ${ }^{49}$. Murzynowski postulował, by kandydaci na ławników legitymowali się niezwykle wysokimi kwalifikacjami społecznymi, moralnymi i umysłowymi ${ }^{50}$. Dążenie do zapewnienia takich kwalifikacji ławników nie może jednak prowadzić od niezasadnego w świetle art. 60 Konstytucji RP ograniczenia w dostępie do służby publicznej. Prawodawca stawia przed kandydatami na ławników SN następujace wymagania (art. $59 \S 3$ ustawy o SN): posiadanie wyłacznie obywatelstwa polskiego i korzystanie z pełni praw cywilnych i publicznych; nieskazitelny charakter; ukończenie 40 lat; nieukończenie w dniu wyboru 60 lat; bycie zdolnym, ze względu na stan zdrowia, do pełnienia obowiązków ławnika SN; posiadanie co najmniej wykształcenia średniego lub średniego branżowego. Porównując brzmienie przepisu art. $59 \S 3$ ustawy o SN i art. $158 \S 1$ p.u.s.p. (określającego wymagania niezbędne do objęcia urzędu ławnika sądu powszechnego) dostrzegalne różnice sprowadzają się do trzech punktów wyższego minimalnego wieku objęcia urzędu i niższego wieku skutkującego złożeniem urzędu przez ławnika SN (odpowiednio 40 i 60 lat w porównaniu z 30 i 70 lat w odniesieniu ławników sądów powszechnych) oraz braku konieczności ogniskowania swojej aktywności życiowej w miejscu kandydowania od co najmniej roku ${ }^{51}$. Ustawodawca nie przewidział jednak żadnego wymogu w postaci obowiązku posiadania stażu ${ }^{52}$ ławniczego przez ławnika SN. Może się zatem zdarzyć, że zasiadając w składzie 7-osobowym rozpoznającym skargę nadzwyczajna, ławnik po raz pierwszy ujrzy salę sądową. Powyższe niedopatrzenie ustawodawcy wymaga pilnej ingerencji. Skoro bowiem ustawodawca stawia coraz to wyższe wymogi w zakresie kwalifikacji zawodowych co do

${ }^{48}$ Małolepszy, Głuchowski (2018): 89.

49 Piasecki (2005): 239.

50 Murzynowski (1970): 564.

51 Brak temu wymogu jest oczywisty - w innym wypadku ławnikami SN mogliby zostawać wyłącznie mieszkańcy Warszawy.

${ }^{52}$ Choć doświadczenie ławnika jest nieocenione w jego pracy, tej cechy sędziego społecznego nie należy przeceniać. Borucka-Arctowa (1970: 65) trafnie podnosi, że ławnicy o długim stażu zawodowym mają tendencję do utraty wrażliwości społecznej i preferencję do przesuwania się w kierunku „modelu” sędziego zawodowego, który ściśle przestrzega „litery prawa”. 
sędziów sądów różnych szczebli ${ }^{53}$, to te same argumenty powinny przemówić za wprowadzeniem cenzusu doświadczenia ławniczego wobec kandydatów na ławników SN. Jeśli ustawodawca deklaruje, że ławnicy przy rozpoznawaniu spraw mają równe prawa z sędziami i asesorami, zapewnia ich formalne równouprawnienie i zespolenie i zrównuje ich prawa z sędziami zawodowymi ${ }^{54}$, to powstaje pytanie, dlaczego przed kandydatami na sędziów społecznych SN nie stawia cenzusu w postaci obowiązku legitymowania się doświadczeniem na stanowisku ławnika. Niezwykle zawiły charakter spraw badanych w nowo utworzonych Izbach Sądu Najwyższego nakazywałby raczej włączyć w orzekanie ławników doświadczonych niż tych, którzy dopiero rozpoczynają swoja służbę.

Przepis art. $64 \S 1$ ustawy o SN przewiduje, że funkcja ławnika Sądu Najwyższego wygasa w przypadku prawomocnego skazania za umyślne przestępstwo ścigane $\mathrm{z}$ oskarżenia publicznego lub umyślne przestępstwo skarbowe lub w przypadku stwierdzenia, że ławnik Sądu Najwyższego pełnił służbę, pracował lub był współpracownikiem organów bezpieczeństwa państwa, wymienionych w art. 5 ustawy z 18 grudnia 1998 r. o Instytucie Pamięci Narodowej - Komisji Ścigania Zbrodni przeciwko Narodowi Polskiemu. Marszałek Senatu stwierdza wygaśnięcie funkcji z tego powodu i informuje o tym Pierwszego Prezesa Sądu Najwyższego. Ustawa nie precyzuje powodów odwołania ławnika Sądu Najwyższego. Oznacza to, że wobec zastosowania odesłania do przepisów p.u.s.p. przyczyny ustania funkcji ławnika SN są tożsame z przyczynami ustania funkcji ławnika sądu powszechnego. Zatem, zgodnie z przepisami art. 71 ustawy o SN w zw. z art. $166 \S 1$ i 2 pkt $2-4$ p.u.s.p., mandat ławnika SN wygasa w razie prawomocnego skazania na przestępstwo bądź wykroczenie, w tym również za przestępstwo lub wykroczenie skarbowe. Istotnym zagadnieniem pozostaje to, jaki organ będzie władny do stwierdzenia wygaśnięcia mandatu bądź fakultatywnego odwołania ławnika. O ile bowiem w p.u.s.p. wskazano wyraźnie, że organem tym jest ten sam organ, który powołuje ławników sądów powszechnych (rada gminy), o tyle regulacja ustawy o SN milczy w tej kwestii. Stoję na stanowisku, że to Senat będzie kompetentnym organem do odwołania ławnika SN z zajmowanej funkcji (art. 71 ustawy o SN w zw. z art. $166 \S 2$ p.u.s.p.). Procedurą odwołania ławnika SN i ławnika sądu powszechnego powinien rządzić ten sam schemat, za czym przemawia logika posunięć prawodawcy i konsekwencja w wyborach aksjologicznych. Dlatego też Senat może odwołać ławnika SN na wniosek Pierwszego Prezesa SN w przypadku: niewykonywania obowiązków ławnika, zachowania godzacego w powagę SN oraz niezdolności do wykonywania obowiązków ławnika.

${ }^{53}$ Wymóg posiadania stażu: 3 lat pracy na stanowisku asesora wobec kandydata na stanowisko sędziego sądu rejonowego (art. $61 \S 1$ pkt 7 p.u.s.p.), 4 lat pracy na stanowisku sędziego sądu rejonowego wobec kandydata na stanowisko sędziego sądu okręgowego (art. 63 § 1 p.u.s.p.), 10 lat pracy na stanowisku sędziego na stanowisko sędziego sądu apelacyjnego (art. 64 § 1 p.u.s.p.), 10 lat pracy na stanowisku sędziego dla objęcia stanowiska sędziego SN (art. $30 \S 1$ pkt 7 ustawy o SN).

${ }^{54}$ Gudowski (2009): 40. 


\section{SZANSE I ZAGROŻENIA ZWIĄZANE Z INSTYTUCJĄ LAWNIKÓW SN}

Wprowadzenie do polskiego porządku prawnego instytucji ławników SN niesie za sobą dwa aspekty: pozytywny - wyrażajacy się w zauważeniu przez ustawodawcę konieczności ciagłego rozwijania normy wyrażanej przez art. 182 Konstytucji RP i zwiększenia udziału czynnika społecznego w sprawowaniu wymiaru sprawiedliwości, oraz negatywny - sprowadzający się do umieszczenia sędziów społecznych w strukturze Najwyższej Instancji Sądowej. Nie można stracić z pola widzenia faktu, że czynnik społeczny włączono w rozstrzyganie w postępowaniach, w których weryfikuje się prawidłowość prawomocnych orzeczeń. Zmiana ma charakter bezprecedensowy. Ocena nowej instytucji nie jest łatwym zadaniem, jednakże siła argumentów przemawiających przeciwko niej przeważa. Można bronić tezy, że wskutek wprowadzenia instytucji ławników SN poddano postępowania toczące się przed tym Sądem realnej kontroli społecznej. Nie ma jednak przekonujących argumentów przemawiajacych za teza, że jedynie tworzenie składów mieszanych z udziałem ławników stanowi wyraz doniosłej kontroli społecznej orzecznictwa SN. Samo założenie projektodawców czynienia z ławnika SN „elementu kontroli społecznej” aktualizuje pytanie o możliwość rzetelnego wypełniania funkcji orzeczniczej i bezstronność zewnętrzną ławnika.

Udział ławników w orzekaniu nie jest jednak wyłączną formą realizacji zasada udziału czynnika społecznego w sprawowaniu wymiaru sprawiedliwości. Jej gwarancjami są też jawność postępowań i udział organizacji społecznych w postępowaniach w charakterze quasi-stron lub amicus curiae. Szereg organizacji pozarządowych zajmujacych się ochrona praw człowieka prowadzi działania polegające na obserwacji rozpraw, niemal na każdym szczeblu struktury wymiaru sprawiedliwości w celu diagnozowania poziomu przestrzegania gwarancji procesowych, składających się na prawo do rzetelnego procesu ${ }^{55}$. O skuteczności tych działań oddolnych nie trzeba nikogo przekonywać. Istotne znaczenie ma również udział w procesie przedstawiciela społecznego na zasadach wyrażonych w art. 90-91 k.p.k., czy wreszcie uczestnictwo w procesie „przyjaciela sądu”, będące najpełniejszym sposobem wyrażania stanowiska przez organizacje spo$ł_{\text {łeczne }}^{56}$ i oceniane nierzadko bardziej pozytywnie niż udział ławników ${ }^{57}$. Czy tego rodzaju różnorodna aktywność nie jest najdonioślejszym nośnikiem głosu społeczeństwa? Znamienne, że przy wprowadzeniu instytucji ławników SN nadal trudno dostrzec realne wsparcie ustawodawcy dla oddolnych działań obywatelskich związanych z udziałem społeczeństwa w procesie karnym.

Nie bez znaczenia pozostaje pytanie o to, dlaczego jedynie część postępowań prowadzonych przed SN objęto rozpoznaniem w składach ławniczych. Przy powierzeniu sędziom społecznym orzekania w sprawach wywołanych wniesieniem skargi nadzwyczajnej (która może dotyczyć każdej dziedziny prawa pozostającej w kognicji sądów powszechnych) sprawy rozpoznawane w Izbie Karnej, Cywilnej

\footnotetext{
55 Wilamowski (2006): 13.

56 Wilamowski (2006): 32.

57 Resich (1973): 58.
} 
i Pracy i Ubezpieczeń Społecznych powierzono składom wyłącznie zawodowym. Wattpliwości budzi również partycypacja ławników w wydawaniu wyroków po rozpoznaniu metaśrodków zaskarżenia, skoro nie uczestniczą w rozpoznawaniu spraw w postępowaniu odwoławczym. Sam argument o ograniczaniu przez ławnika „szablonu i rutyny” w orzecznictwie w przypadku spraw rozpoznawanych przez SN jest niewystarczający. Ze względu na daleko posuniętą specyfikę spraw rozpoznawanych z udziałem ławników SN, ich merytoryczny wkład do orzecznictwa nowych izb SN stoi po znakiem zapytania. Przy tym nie należy tracić z pola widzenia tego, że choć ławnik jest niezawisłym członkiem składu orzekającego, to jego rola w sprawowaniu wymiaru sprawiedliwości jest zgoła inna niż sędziego zawodowego. Ubranie ławnika w szaty osoby znającej prawo, może jedynie pozornie przynieść dobry efekt ${ }^{58}$.

Nie bez znaczenia pozostaje sama natura stosunków pomiędzy ławnikami SN a sędziami zawodowymi tegoż sądu. Nie można w tej mierze czynić żadnych prognoz, lecz warto podkreślić, że prowadzone badania empiryczne ${ }^{59}$ wykazały częstą niezgodność poglądów pomiędzy sędziami zawodowymi a społecznymi. Sam brak zaufania w składach orzekających poczytuje się z kolei za główny mankament działalności składów mieszanych ${ }^{60}$. W badaniach empirycznych ustalono także, że większa wiedza prawnicza u sędziego stanowiła jedną z głównych przyczyn różnic zdań ławników i sędziów ${ }^{61}$. Ta dysproporcja na poziomie sądów pierwszoinstancyjnych może być w prosty sposób likwidowana wkładem ławnika do sprawy w zakresie oceny okoliczności faktycznych, co nie wydaje się tak oczywiste w postępowaniu prowadzonym przed SN.

Sporym zaskoczeniem jest nagły zwrot preferencji aksjologicznych ustawodawcy, który jeszcze w 2007 r. skutecznie ograniczył udział sędziów społecznych w rozpoznawaniu spraw przez sądy I instancji. Podnoszono wówczas: „Projekt niniejszy jest kolejnym przejawem potrzeby zminimalizowania instytucji sądów ławniczych na rzecz sądownictwa zawodowego, wysoko kwalifikowanego i usytuowanego na poziomie uwieńczenia kariery prawniczej. Jeżeli bowiem wymiar sprawiedliwości ma spełnić rolę, jaka przypada mu w demokratycznym państwie prawa, tak jako gwarant praworządności, jak i trzecia władza stwarzająca obywatelom poczucie bezpieczeństwa i ochrony ich praw takie zmiany sa konieczne" ${ }^{62}$. Biegunowa zmiana determinant realizacji zasady udziału czynnika społecznego w sprawowaniu wymiaru sprawiedliwości nie sprzyja prawidłowej realizacji deklaracji wyrażonej w art. 182 Konstytucji RP, stabilności władzy sądowniczej ani powadze wymiaru sprawiedliwości. Tego rodzaju zmianę preferencji należy ocenić krytycznie. Stanisław Waltoś, odnosząc się do uzasadnienia nowelizacji z 2007 r., nie bez racji wskazywał, że: „Finezja perfidii rozumowania ściga się w niej z cyniczną sofistyką"63.

58 Turska (1970): 195.

59 Wenclik (2011): 72, cyt. [za:] Siemaszko (1994).

60 Murzynowski (1970): 565.

61 Borucka-Arctowa (1970): 62.

62 Druk sejmowy nr 639, Sejm V kadencji, projekt ustawy o zmianie ustawy przepisy wprowadzające Kodeks postępowania karnego, Dz. U. Nr 89, poz. 556 ze zm.: 1-2.

63 Waltoś (2011): 528. 
Jakkolwiek nie budzi istotniejszych wątpliwości, że realizacja zasady udziału czynnika społecznego w sprawowaniu wymiaru sprawiedliwości stanowi wyraz demokratyzacji prawa karnego procesowego i niepodważalna, historyczną cechę polskiego wymiaru sprawiedliwości, to może zastanawiać, czy wprowadzenie instytucji ławników SN, wraz z wejściem w życie ustawy o SN, przyczyniło się do wzmocnienia więzi sądownictwa ze społeczeństwem. Udział sędziów społecznych w orzekaniu w ramach składów mieszanych jest pożądanym zjawiskiem i poprawna formą realizacji zasady wymienionej w art. 182 Konstytucji RP. O ile wprowadzanie czynnika społecznego do kompetencji aparatu państwa jest wyrazem demokratycznego i humanistycznego sprawowania władzy, to ma ona sens o tyle tylko, o ile oparta jest na szczerych intencjach ${ }^{64}$. Rzecz w tym, że pożądanym miejscem pracy ławników - sędziów, przedstawicieli społeczeństwa i buforów wrażliwości obywatelskiej jest sąd rozpoznający sprawę w I instancji. W tym sądzie ławnicy mogą wykazać się spostrzegawczościa, zaangażowaniem, wrażliwością obywatelską i wywierać realny wpływ na treść wydawanego orzeczenia ${ }^{65}$. Rozpoznając sprawy pierwszoinstancyjne, w których spór zasadza się głownie na płaszczyźnie faktów i oceny dowodów, a także w ogólnym zarysie na dochodzeniu do prawdy materialnej, ławnicy mogą stanowić nieoceniona pomoc dla sędziów - przewodniczących składów kolegialnych. Trudno nie zgodzić się jednak z poglądem, że uczynienie trzyosobowego składu sędziowskiego składem rozpoznającym sprawy w pierwszej instancji jest choćby z przyczyn ekonomicznych niemożliwe ${ }^{66}$. Trafnie podnosi się jednak, że demokratycznego państwa prawnego nie stać na tego rodzaju oszczędności ${ }^{67}$. Ostatecznie ustawodawca nie zdecydował się jednak na naprawienie błędu, jakim była nowelizacja z 2007 r. Prawodawca poszukał dla ławników nowego miejsca w drabinie organów wymiaru sprawiedliwości, znajdując je w SN. Jest to rozwiązanie chybione.

Suma wątpliwości o charakterze dogmatycznoprawnym, a także instytucjonalne wady nowej instytucji oraz wprowadzenie jej w życie w atmosferze gorącego sporu społeczno-politycznego każą podać w wątpliwość intencje projektodawców, czy wprowadzenie składów ławniczych do SN przyczyni się do prawidłowej realizacji konstytucyjnej i kodeksowej zasady sprawowania wymiaru sprawiedliwości z udziałem czynnika społecznego. Niewątpliwie ostateczną ocenę zdeterminuje dopiero praktyka orzecznicza składów ławniczych, jednakże już na gruncie dogmatycznym obawy są uzasadnione.

\section{Michat Basa}

Uniwersytet Wroctawski

michal.basa@uwr.edu.pl

https://orcid.org/0000-0002-5120-5693

\footnotetext{
64 Pożaroszczyk (2013): 178.

65 Kubicki (1970): 105.

${ }^{66}$ Klubińska (2018): 17.

${ }^{67}$ Klubińska (2018): 23.
} 
Borucka-Arctowa, M. (1970). Rola ławnika w świetle poglądów samych ławników oraz przedstawicieli środowiska prawniczego, [w:] S. Zawadzki, L. Kubicki (red.), Udział ławników w postępowaniu karnym. Opinie a rzeczywistość. Studium prawnoempiryczne. Warszawa: $29-62$.

Grzegorczyk, T. (2015). Kasacja jako nadzwyczajny środek zaskarżenia w sprawach karnych i jej skuteczność w praktyce. Państwo i Prawo 70(6): 19-38.

Gudowski, J. (2009). Komentarz do art. 4, 158-172 p.u.s.p., [w:] J. Gudowski, T. Ereciński, J. Iwulski (red.), Prawo o ustroju sądów powszechnych. Ustawa o Krajowej Radzie Sądownictwa. Komentarz. Warszawa: 38-43, 634-655.

Jakubik, M. (2014). Czynnik społeczny w składzie sądu w znowelizowanym kodeksie postępowania karnego, [w:] T. Gardocka, M. Jakubik (red.), Szkice o nowym modelu procesu karnego. Warszawa: 37-49.

Klubińska, M. (2018). Udział ławników w procesie karnym z perspektywy funkcji postępowania głównego, [w:] D. Kala, I. Zgoliński (red.), Postępowanie przed sądem I instancji w znowelizowanym procesie karnym. Warszawa: 15-25.

Kluza, J. (2019). Skarga nadzwyczajna w postępowaniu karnym. Ius Novum 13(1): 45-64.

Kosonoga, J. (2016). Skład sądu na rozprawie głównej. Ius Novum 10(4): 83-101.

Kotowski, A. (2018). Skarga nadzwyczajna na tle modeli kontroli odwoławczej. Prokuratura i Prawo 73(9): 51-85.

Kubicki, L. (1970). Udział ławników w orzekaniu, [w:] S. Zawadzki, L. Kubicki (red.), Udział ławników w postępowaniu karnym. Opinie a rzeczywistość. Studium prawnoempiryczne. Warszawa: 69-106.

Kutnjak Ivkovic, S. (2003). An inside view: professional judges' and lay judges' support for mixed tribunals. Law and Policy 25(2): 93-122.

Małolepszy, M., Głuchowski, M. (2018): Participation of lay judges in criminal proceedings in Poland and Germany. Ius Novum 12(2): 86-106.

Masternak-Kubiak, M. (2014). Komentarz do art. 182 Konstytucji RP, [w:] M. Haczkowska (red.), Konstytucja Rzeczypospolitej Polskiej. Komentarz. Warszawa: 460-463.

Murzynowski, A. (1970). Refleksje na temat instytucji ławników. Państwo i Prawo 25(10): 558-567.

Murzynowski, A. (1994). Istota i zasady procesu karnego. Warszawa.

Nowicki, M.A. (2017). Wokół Konwencji Europejskiej. Komentarz do Europejskiej Konwencji Praw Człowieka. Warszawa: Lex/el. 2017.

Piasecki, K. (2005). Organizacja wymiaru sprawiedliwości w Polsce. Warszawa.

Pożaroszczyk, D. (2013.) Refleksje na temat instytucji ławników w polskim procesie karnym, [w:] B.T. Bieńkowska, D. Szafrański (red.), Problemy prawa polskiego i obcego w ujęciu historycznym, praktycznym i teoretycznym. Część 4. Warszawa: 173-183.

Prusak, F. (1975). Czynnik społeczny w procesie karnym. Warszawa.

Resich, Z. (1973). Nauka o organach ochrony prawnej. Warszawa.

Rogacka-Rzewnicka, M. (2001). Kasacja w polskim procesie karnym. Warszawa.

Rybicki, M. (1964). Ławnicy ludowi w sądach powszechnych. Ustawa o ławnikach ludowych i przepisy związkowe. Słowo wstępne Ministra Sprawiedliwości Mariana Rybickiego. Warszawa: $3-12$.

Rybicki, M. (1968). Ławnicy ludowi w sądach PRL. Warszawa.

Siemaszko, A. (1994). Ławnicy: rezultaty badań empirycznych. Warszawa.

Śliwiński, S. (b.r.). Ławnik, [w:] W. Makowski (red.), Encyklopedia podręczna prawa karnego. Tom 2. Warszawa: 862-864.

Turska, A. (1970). Analiza odrębności postaw ławnika i sędziego zawodowego w orzekaniu, [w:] S. Zawadzki, L. Kubicki (red.), Udział ławników w postępowaniu karnym. Opinie a rzeczywistość. Studium prawnoempiryczne. Warszawa: 107-158.

Waltoś, S. (2011). Ławnik - czy piąte koło u wozu? [w:] T. Grzegorczyk (red.), Funkcje procesu karnego. Księga jubileuszowa Profesora Juliusza Tylmana. Warszawa: 523-533.

Waszczyński, J. (1969). Ustrój organów ochrony prawnej. Łódź.

Wenclik, M. (2011). Ewolucja instytucji ławnika w Polsce, [w:] J. Ruszewski (red.), Ocena funkcjonowania i procesu wyboru ławników sądowych na przykładzie sądów Apelacji Białostockiej. Suwałki: $65-74$. 
Wilamowski K. (2006). Obserwacja procesu karnego jako instrument działania organizacji pozarządowej w sprawach indywidualnych. Warszawa.

Wiliński, P., Karlik, P. (2016). Komentarz do art. 182 Konstytucji RP, [w:] M. Safjan, L. Bosek (red.), Konstytucja RP. Tom 2: Komentarz do art. 87-243. Warszawa. [Online] Legalis.

\section{SUPREME COURT LAY JUDGES}

\section{Sum mary}

Attempts to prosecute crimes without the involvement of the public are certain to end in a fiasco (Stanisław Waltoś). On 3 April 2018, the Act of 8 December 2017 on the Supreme Court entered into force (Journal of Laws of the Republic of Poland of 2019, item 825, consolidated text). The aforementioned act introduced lay judges to the Supreme Court. The lay judges of the Supreme Court are to rule on cases examined in second instance in the Chamber of Disciplinary Proceedings, and in cases brought by an extraordinary petition. The changes made seem to express the principle of the participation of the citizenry in justice, as articulated in Article 182 of the Constitution of the Republic of Poland. In fact, these changes appear to be groundbreaking and pose a number of risks to the proper functioning of the judiciary. The changes raise doubts as to whether lay judges will have jurisdiction in the cases examined in the Chamber of Extraordinary Control (which involve a considerable degree of legal complexity). Furthermore, the participation of lay judges in the courts of appeal is a solution hitherto unknown in the Polish legal system. Moreover, a sudden turn in the axiological preferences of the legislature is noticeable. The Legislature amended the Code of Criminal Procedure in 2006 (JL RP No. 89, item 556, as amended) and clearly expressed a critical attitude to the institution of lay judges, pointing out the need to professionalize the judiciary. The presidential draft bill on the Supreme Court signals a crucial difference. The insufficient social legitimacy of the new law is also relevant. The implementation of this law in an atmosphere of heated socio-political dispute also raises questions. The implementation of systemic changes in the justice system, in violation of the conditions of good legislation, should meet with firm criticism

Keywords: lay judges; law on Supreme Court; Supreme Court; extraordinary action; disciplinary chamber; chamber of extraordinary control and public affairs; composition of the court 
